\title{
A Work in Progress: The United Kingdom's Campaign Against Radicalization
}

\author{
James Wither *
}

I speak to you today about the blessed raid in London which came as a blow to the insolent British Crusader pride and made it sip from the same glass from which it had long made the Muslims drink.

- Ayman Al-Zawahiri

\section{Introduction}

The United Kingdom (U.K.) has ample experience of terrorism. Over three thousand people were killed during the thirty-year-long campaign by the Provisional Irish Republican Army (PIRA) for a united Ireland. However, the death toll from a single attack never exceeded twenty-nine, and the British public developed a certain stoicism in the face of intermittent bombings in London and other British cities. Like other European separatist groups, PIRA sought to establish legitimacy and broaden support by largely restricting its killings to representatives of the British government, members of the security forces, and collaborators. ${ }^{1}$ Indiscriminate attacks on civilians were generally avoided, and warnings were often sent to the British authorities before bomb attacks on civilian or infrastructure targets. When suicide bombers struck the London transport system without warning on 7 July 2005, killing fifty-two people and injuring over seven hundred, it marked a stark departure from PIRA's methods and highlighted the fact that the U.K. faced a terrorist threat far more ruthless and dangerous than anything that had preceded it.

Since the 1970s, comprehensive anti-terrorist measures in the U.K., including tough legislation, evolved to keep pace with an able and adaptive adversary. Nevertheless, the battle against PIRA provides few if any lessons for dealing with ideologically motivated terrorists. Although Irish republicanism was nominally a social revolutionary movement, its leaders had little regard for radical political or religious ideologies. Splinter groups-like the Irish National Liberation Army (INLA)-that embraced Marxist-Leninism never had more than minimal support amongst republicans. As in any counter-insurgency, "winning hearts and minds" was an important component of British strategy in Northern Ireland, but the U.K. was not confronted by terrorists who were motivated by a radical and uncompromising ideology. Unlike France, Britain did

* James Wither is Professor of National Security Studies at the George C. Marshall European Center for Security Studies. The views in this paper are those of the author and do not reflect the viewpoint of the governments of the United Kingdom, the United States, or the Federal Republic of Germany.

1 Families of service personnel and people who were associated or worked with the security forces were also regarded as legitimate targets. 
not experience terrorism by Muslim radicals in the 1990s. The intelligence services monitored Islamic radicals in the U.K., but until the attacks of 11 September 2001, the main counterterrorism effort remained focused on Irish republican dissidents who rejected the peace process in Northern Ireland. Consequently, radical Muslim militants and preachers, such as Abu Hamza and Abdallah al Faisal, were able to exploit relatively lax asylum procedures and find refuge in the U.K. in the 1990s to propagate their extremist version of Islam.

After 2001, the U.K. became a major focus for what is now generally referred to as Islamist terrorism, ${ }^{2}$ not least because of the government's active support for United States military operations in Iraq and Afghanistan. Before July 2005, the British authorities disrupted several potential attacks_including an attempt by a cell affiliated with Al Qaeda to produce chemical weapons in 2003-but the security services and intelligence agencies acknowledged that a successful attack was to be expected. ${ }^{3}$ It was also apparent that the threat came not only from foreign jihadists but also from Britishborn, home-grown radicalized Muslims. A mounting awareness of the danger posed by the latter made efforts to identify and address the sources of radicalization at home and abroad a matter of major importance for the British government. These efforts acquired a new urgency after the July 2005 bombings and the discovery of further terrorist plots involving British citizens.

This article examines the problem of countering ideological support for terrorism (CIST) in the U.K. For convenience, the American acronym CIST is used in the paper, although this is not a common term in the United Kingdom. Instead, British officials and commentators normally refer to "understanding and combating radicalization." The paper is structured into five parts, covering the ideology of Islamist terrorism; the sources of radicalization; the motivation and background of U.K. terrorists; British government policies to address radicalization; and the barriers to effective implementation of CIST measures.

\section{The Ideology of Islamist Terrorism}

At a speech in parliament on 10 July 2006, the Secretary of State for the Home Department, John Reid, described the ideological threat confronting the U.K. in the following terms:

2 Islamism refers to political ideologies derived from the beliefs of Muslim fundamentalists who believe that Islam is not only a religion but also a holistic system that provides the complete political, legal, economic, and social foundations for society. Islamist is the term generally used by Western analysts to denote radicals at the extreme end of the fundamentalist spectrum that have resorted to terrorism. However, Islamism is not synonymous with terrorism. Many Islamist groups have renounced or avoided violence. Politics (rather than violence) gives mainstream Islamist groups their growing influence in many parts of the world. Intelligence and Security Committee, Report into the London Terrorist Attacks on 7 July 2005, Cm. 6785 (London: The Stationery Office, May 2006), 9-10. 
... the people involved in those terrorist attacks are driven by a very particular and violent ideology. A common thread running through terrorist attacks of the past decade has been a claim by those involved that they have been acting in defence of Islam. It is crucial that we understand that the extreme interpretation espoused by Islamist terrorists to support their actions is not an interpretation of Islam that is shared by the vast majority of Muslims in the U.K. and abroad. ${ }^{4}$

As a set of universal principles, a system of values, or as blueprints for an ideal society, ideologies can offer potent justifications for terrorism. Zealots can claim that sacrifice and violence are perpetrated in the service of a higher cause. Revolutionary Marxist-Leninism provided the main stimulus for twentieth-century ideologically motivated terrorism, but since the collapse of the Soviet Union, radical Islamism has supplanted it as the terrorist ideology of choice. Marxist-Leninist terrorist groups of the Cold War era were prepared to use ruthless violence to achieve their objectives, but indiscriminate attacks on civilians were rare. By contrast, the rise of Islamist terrorism since the 1980s has been characterized by the use of suicide attacks intended to cause maximum civilian casualties, justified by the perpetrators on both strategic and ideological grounds. It has also raised the hitherto unthinkable prospect of a catastrophic terrorist attack involving weapons of mass destruction (WMD).

The philosophical roots of Muslim militancy are complex, and it is not possible to do justice to this complexity in the short summary offered here. ${ }^{5}$ Nevertheless, some background is necessary to provide insights into the nature of the ideology that inspires Islamist terrorism in the U.K. and elsewhere. Since Islamism supplanted Arab secular socialism and pan-Arabism in the 1980s, Islamists have sought to offer a simple ideological solution to the Muslim world's contemporary problems in the form of return to the fundamentals of Islam as an all-encompassing religious, political, and social system. The most severe Islamists are normally referred to as Salafists, ${ }^{6}$ although not all members of this Sunni group advocate violent methods to purify Islam. Islamists generally share a common religious perspective, but often differ in their interpretation of

4 House of Commons Hansard Debates for 10 July 2006 (pt 0850), Col. 1116. As head of the Home Office, John Reid is the U.K. government minister primarily responsible for tackling domestic terrorism.

5 Recent analyses can be found in Robert Reilly, The Roots of Islamist Ideology (London: Centre for Research into Post-Communist Economies, February 2006); Nathan J. Brown, Amr Hamzawy, \& Marina Ottaway, Islamist Movements and the Democratic Process in the Arab World, Carnegie Papers No. 67 (Washington, D.C.: Carnegie Endowment, March 2006), available at www.CarnegieEndowment.org/pubs; and Quintan Wiktorowicz, "Anatomy of the Salafi Movement," Studies in Conflict and Terrorism 29:3 (May 2006): 207-39.

6 The Arabic word Salaf means "predecessors or early generations," and literally refers to the first three generations of Muslims (those who were companions of Muhammad and the two generations following). Salafism refers to a fundamentalist version of Islam as supposedly practiced by the first few generations of Muslims. The creed transcends cultural and national differences. The term is often used synonymously with Wahhabism. Qutbism, named after the Egyptian Islamist ideologue Sayyid Qutb, is sometimes used to describe violent radicals to distinguish them from non-violent Salafi purists. 
contemporary politics and events. Under the Islamist umbrella are scholars who focus exclusively on non-violent methods of conversion, political activists who seek to achieve power through the ballot box, and militant jihadists who reject the concept of the nation-state and advance their agenda through violence and revolution.

Islamism offers pride in a common religious identity to relieve the feelings of anger, frustration, and humiliation felt by many in the Muslim world. These emotions are aroused by many different factors, including the economic and political backwardness of much of the Middle East, but a perception that the Western powers are the source of the Muslim world's ills has reinforced a sense of grievance. Osama bin Laden, as leader of Al Qaeda, has effectively played on Muslim anger to gain support for his radical agenda. In a message after the 9/11 attacks, he claimed: "Our nation has been tasting this humiliation and contempt for more than eighty years. Its sons are being killed. Its blood is being shed, its holy places attacked and it is not being ruled according to what God has decreed." Consequently, Al Qaeda has proved capable of mobilizing support across class, ethnic, and intra-Islamic sectarian boundaries.

Islamist ideology has led to the creation of widespread, grass-roots social networks throughout the Middle East and, in states that have permitted their formation, Islamic political parties are well established as a legitimate electoral force. But the same philosophy - as it evolved in Egypt, where the Islamist movement faced brutal repression-provided the ideological basis for a particularly virulent form of extremism. The philosophical foundations of the movement are rooted in the Sunni Salafi school of Islam, and in the works of the seminal Islamist thinkers Hassan al Banna (the founder of the Muslim Brotherhood) and Sayyid Abdul Ala Mawdudi. However, neither Mawdudi nor al Banna advocated terror; the first true theorist of Islamist terrorism was the Egyptian writer Sayyid Qutb, who was executed in Egypt in 1966. He married a Salafist interpretation of the Koran with radical socio-political theory.

Like Marxist-Leninism, Qutb envisaged a totalitarian, universalistic, revolutionary ideology characterized by utopian ideals and coupled with contempt for alternative political or religious systems and beliefs. Although Qutb was strongly opposed to communism, his concept of using revolutionary vanguards to mobilize the masses for Islam directly echoed Lenin's concept of a "Vanguard of the Proletariat." It is not surprising that a number of analysts have described the radical Islamist movement that he spawned as a form of Islamic Leninism. ${ }^{8}$ Qutb's advocacy of violence and his claim that it is the religious duty of Muslims to challenge the authority of non-Islamist governments was a major influence on Iranian revolutionaries and later groups such as Hezbollah, Islamic Jihad, and Al Qaeda.

The Soviet invasion of Afghanistan was a seminal event in the evolution of Islamist extremism, as it brought together fighters from different strands of radical Islam and

\footnotetext{
Broadcast on Al-Jazeera Satellite Television (in Arabic), Doha, Qatar (7 October 2001).

8 See, for example, Reilly, Roots of Islamist Ideology, 9; Thomas Friedman, The World is Flat: A Brief History of the Globalized World in the $21^{\text {st }}$ Century (New York: Farrar, Straus \& Giroux, 2005), 393-95; and John Gray, Al Qaeda and What It Means to be Modern (London: Faber \& Faber, 2003), 3-4.
} 
revived the idea of jihad to evict foreign occupiers from Muslim territory. In this context, Abdullah Yusuf Azzam, known as the "Godfather of Jihad," is of particular note, as he helped develop the concept of a global terrorist network by placing Islamic universalism above considerations of sectarianism or nationalism. ${ }^{9}$ Osama bin Laden and his deputy and chief ideologist Ayman al-Zawahiri have built on the legacy of radical Islamist thinkers to create the principles and strategy that support Al Qaeda's global jihad. In 1998, in another echo of revolutionary Marxism, bin Laden announced the creation of the "World Islamic Front for Jihad Against Jews and Crusaders." ${ }^{10}$ His intention was to erect an umbrella organization for Islamist groups from Morocco to China.

Over time, the basic religious and political agenda of Al Qaeda has remained consistently focused on two major goals: the expulsion of foreign forces and influences from Muslim societies and the ultimate creation of an Islamic caliphate ruled by sharia law. ${ }^{11}$ The concept of armed resistance, or defensive jihad, is central to Al Qaeda's thinking, as it appeals to the collective religious duty of all Muslims to come to the defense of the faith. The two key Al Qaeda policy statements of the 1990s both invoked defensive jihad, but also demonstrated the terrorist group's intention to take the war to America and its allies - the "far enemy," as opposed to the "near enemy" against which jihad could also be directed (insufficiently pious Muslim rulers of Muslim lands). In the Declaration of Jihad Against the Americans Occupying the Land of the Two Holy Mosques, ${ }^{12}$ issued in 1996, bin Laden described his enemies as the "alliance of Jews, Christians and their agents," and condemned the U.S. presence in Saudi Arabia and U.S. support for Israel. Defensive jihad was also invoked in the 1998 fatwa, which called for armed resistance and ruled that "to kill the Americans and their allies-civilians and military_-is an individual duty for every Muslim...." ${ }^{13}$ In 2002, bin Laden made a further unequivocal statement that he regarded all Americans as legitimate tar-

9 Al Azzam's uncompromising slogan “Jihad and the rifle alone: no negotiations, no conferences and no dialogues” is said to have inspired bin Laden, among others. See the page on Azzam at the website of Perspectives on World History and Current Events: Middle East Project, at www.pwhce.org/azzam.html.

10 This formed part of the 1998 fatwa urging jihad against the U.S. This organization was replaced by a new framework called Qa'idat al-Jihad (The Jihad Base) in spring 2002. See Ely Karmon, “Al-Qa'ida and the War on Terror After the War in Iraq,” Middle East Review of International Affairs 10:1 (March 2006): 2.

11 See Christopher Blanchard, Al Qaeda: Statements and Evolving Ideology, CRS Report RL32759 (Washington, D.C.: Congressional Research Service, updated January 2007); available at www.fas.org/sgp/crs/terror/RL32759.pdf.

12 Al Islah (London) (in Arabic) (2 September 1996).

13 “Text of Fatwa Urging Jihad Against Americans,” Al- Quds al- Arabi (London) (in Arabic) (23 February 1998), 3. 
gets. Al-Zawahiri expressed similar sentiments about the British people after the London bombings in July $2005 .^{14}$

Despite the loss of its base in Afghanistan, Al Qaeda remains the inspiration for a whole new generation of Islamist extremists, including the "born-again" converts from the Muslim diaspora who were responsible for the attacks in Madrid and London. The terrorism analyst Marc Sageman has described these European jihadists as groups of friends whose primary motivation is grounded in group dynamics and identity, drawing on support from the "virtual umma" on the Internet. ${ }^{15}$ However, Sageman's findings also stress the importance of a "link to the jihad," which provides the necessary resources and know-how to turn would-be fighters into effective terrorists. ${ }^{16}$ Information emerging from investigations into terrorist activity in the U.K. suggests that contacts with militants in Pakistan are a significant feature of the planning and indoctrination process, although the extent of Al Qaeda's direct involvement in U.K. terrorism remains unclear. ${ }^{17}$

\section{The Sources of Radicalization}

In its report on the London bombings, the U.K. Intelligence and Security Committee stressed the importance of understanding radicalization, especially as the Security Service (normally referred to as MI5) could find "no simple Islamist extremist profile," and concluded that those who appeared to be well assimilated into mainstream British society might pose just as significant a threat as individuals from socially or economically deprived sections of the community. ${ }^{18}$ The British government's counterterrorism strategy paper published in July 2006 offered a preliminary analysis of the potential factors leading to radicalization, but acknowledged that radicalized individuals did not necessarily go on to become terrorists. ${ }^{19}$ Three major factors were put forward for consideration: a sense of grievance and injustice, personal alienation or community

14 Osama bin Laden, "Letter to the American People," text in English, posted at www.waaqiah.com (26 October 2002) (since removed); transcript of Zawahiri’s message regarding the July 2005 bombings on BBC News (16 November 2005); available at http://news.bbc.co.uk/go/pr/fr/-/2/hi/middle_east/4443364.stm.

15 Marc Sageman, Presentation to the Program for Terrorism and Security Studies, George C. Marshall Center for Security Studies, February 2006.

16 Marc Sageman, Understanding Terrorist Networks (Philadelphia: University of Pennsylvania Press, 2004), 120-21.

17 See, for example, Home Office, Report of the Official Account of the Bombings in London on $7^{\text {th }}$ July 2005 (London: The Stationery Office, 11 May 2006), 20, available at www.homeoffice.gov.uk/documents/7-july-report.pdf?view=Binary; and Nicola Woodcock, “Al-Qaeda Wanted Multiple Bombing,” The Times (London) (30 March 2006). In a video broadcast in September 2005, Al-Zawahiri claimed that Al Qaeda launched the bombing attacks in London.

18 Intelligence and Security Committee, Report into the London Terrorist Attacks on 7 July 2005, 29.

19 Countering International Terrorism: The United Kingdom's Strategy, Cm. 6888 (London: The Stationery Office, July 2006), 10. 
disadvantage, and exposure to radical ideas. A wide range of specific issues were also identified as potential influences on the radicalization process both domestically and internationally, including the disruptive impact of globalization, Western policies in the Muslim world, social exclusion and discrimination in the community, and inspirational role models.

The widespread protests in February 2006 against the publication of cartoons depicting the Prophet Muhammad provided a graphic illustration of the antipathy felt by Muslim extremists towards the West. In London, marchers held placards calling for those who insulted Islam to be butchered and promised that Europe would experience its own holocaust, sentiments that are not representative of the majority of British Muslims. The uproar associated with the cartoons contributed significantly to what the Pew Global Attitudes Project has described as a "great divide" separating the viewpoints of Westerners from those of Muslims. ${ }^{20}$ Nevertheless, a low opinion of Western culture and states does not necessarily translate into support for terrorism. The same survey found that 70 percent of British Muslims questioned felt that violence against civilians could not be justified in defense of Islam, although, less reassuringly, 15 percent felt that it could be sanctioned at least "sometimes."21 That a minority of British Muslims appears to support extremism is confirmed by other recent public opinion polls. The Populos poll for The Times and ITV News in July 2006 found that 13 percent of British Muslims surveyed believed that the July 2005 bombers should be regarded as "martyrs," 2 percent would be proud if a family member joined Al Qaeda, and 16 percent would be "indifferent" about such a decision. ${ }^{22}$ A Poll by NOP for Channel 4 reported that 9 percent of Muslims surveyed strongly agreed or tended to agree that the use of violence by political or religious groups was "acceptable." 23

The Iraq war is mentioned as a catalyst for radicalization by a number of sources, not least the U.S. National Intelligence Estimate of April 2006, which described the

20 The Pew Global Attitudes Project, The Great Divide: How Westerners and Muslims View Each Other (Washington, D.C.: Pew Research Center, 22 June 2006); available at http://pewglobal.org/reports/display.php?ReportID=253. The survey found that, although Western and Muslim publics viewed relations between them as generally bad, Europe's Muslim minorities were consistently more moderate than their co-religionists elsewhere in the world.

21 Ibid., 3-4. The Office of National Statistics, using figures from the 2001 census, estimates that there are 1.6 million Muslims in the U.K., with Pakistanis making up the largest nonwhite, ethno-religious group in Britain, with a population of 700,000 concentrated in Birmingham, Bradford, and London. See www.statistics.gov.uk/cci/nugget.asp?id=293.

22 Alexandra Frean and Rajeev Syal, “Muslim Britain Split Over Martyrs of 7/7,” Times Online (4 July 2006); available at www.timesonline.co.uk/tol/news/uk/article682599.ece.

23 Growth from Knowledge, NOP Social Research, Attitudes to Living in Britain-A Survey of Muslim Opinion (27 April 2006), 35; available at www.imaginate.uk.com/MCC01_Survey/ Site\%20Download.pdf. Curiously, the same survey found that 45 percent of Muslims polled believed that the 9/11 attacks were a conspiracy by the U.S. and Israel. 
conflict as the "cause celebre" for jihadists. ${ }^{24}$ Peter Neumann, the Director of the Centre for Defence Studies at King's College London, has stated that "the Iraq War contributed to the radicalization of European Muslims, creating a more supportive environment which Salafi jihadists could draw on for finance and recruits."25 After the foiled plot in August 2006 to blow up aircraft on transatlantic flights, leading British Muslims wrote to Prime Minister Tony Blair to assert that British foreign policy provided "ammunition to extremists." The letter made specific reference to "the debacle of Iraq." ${ }^{26}$ Not surprisingly, the British government has consistently rejected any suggestion that the war has made the U.K. a target for terrorist attack, and calls for a public inquiry into the effects of British foreign policy on Islamist radicalization have been refused. It is debatable whether such an inquiry would have assuaged the feelings of the 31 percent of young British Muslims questioned by the NOP poll in April 2006 who agreed that the July 2005 bombings were justified because of British involvement in "the war on terror," which is perceived by many Muslims as a war against Islam. ${ }^{27}$ As will be discussed below, British foreign and military policies were also cited as motivation by some of the perpetrators of the London attacks.

Recently, some commentators and politicians have highlighted the U.K.'s tolerance of multiculturalism as a factor leading to the apparent alienation of young British Muslims from mainstream influences in society. ${ }^{28}$ The well-meaning attempt by the political establishment over the last twenty years to avoid imposing a single British identity and culture on immigrants to the U.K. is blamed for the self-imposed segregation of Muslim communities, a proliferation of mosques staffed by radical clerics, and the establishment of Muslim religious schools that emphasize Koranic studies and teach South Asian languages. Many Muslims agree that assimilation needs to be improved. For example, the Populus Poll referred to earlier found that 65 percent of British Muslims surveyed felt that their community needed to integrate more fully with the broader U.K. society. ${ }^{29}$ Analysts frequently cite problems of alienation and unfulfilled expectations as a significant factor in the motivation of young European Muslims to join jihadist groups. ${ }^{30}$ Psychiatrist Anne Speckhard suggests that an additional factor is a

24 Declassified Key Judgments of the National Intelligence Assessment, "Trends in Global Terrorism: Implications for the United States,” April 2006; available at http:/www.dni.gov/ press_releases/Declassified_NIE_Key_Judgments.pdf.

25 Peter R. Neumann, “Europe’s Jihadist Dilemma,” Survival 48:2 (Summer 2006): 74.

26 “Full Text: Muslim Groups' Letter,” BBC News (12 August 2006); available at http://news.bbc.co.uk/go/pr/fr/-/2/hi/uk_news/4786159.stm. See also “Miles Apart," The Economist (19 August 2006), 22-23. NOP, Attitudes to Living in Britain, 34.

${ }^{28}$ See, for example, Michael Nazir-Ali, "Multiculturalism is to Blame for Perverting Young Muslims," The Daily Telegraph (15 August 2006); and "British Exceptionalism," The Economist (19 August 2006), 10-11. Frean and Syal, "Muslim Britain Split."

30 See Petter Nesser, "Post-millennium Patterns of Jihadist Terrorism in Western Europe-Part 1," Jane's Terrorism and Security Monitor (15 June 2005): 3; and Tamara Makarenko, “Takfiri Presence Grows in Europe,” Jane’s Intelligence Review (1 February 2005), 3-4. 
conscious repudiation of the perceived corruption of the West through the cleansing embrace of a particularly fundamentalist and militant form of Islam. ${ }^{31}$ Some British Muslims have also argued that the roots of the radicalization problem are economic and social, pointing to relative deprivation, exclusion, and discrimination. ${ }^{32}$ A recent report by the Office of National Statistics concluded that British Muslims were more than twice as likely to be unemployed as followers of other faiths, and up to five times as likely to live in overcrowded conditions. ${ }^{33}$ However, it is hard to establish a direct link between social exclusion and terrorism. Three of the July 2005 bombers, for example, were depicted by the Home Office official report on the attacks as "apparently well integrated into British society."34 Dhiren Barot, a Muslim on trial for a "dirty bomb" plot, has been described as "not the usual image of a terrorist ... born a Hindu and brought up in a north London suburb by middle-class parents." 35

As John Reid's remarks above illustrate, government ministers-anxious not to offend the majority of British Muslims—avoid any suggestion that the religion of Islam itself is to blame for radicalization. The government's counterterrorism strategy paper is at pains to stress that the Muslim communities in the U.K. are not themselves viewed as a security threat. Nevertheless, a number of analysts in the U.K. and elsewhere have argued that violence is inherent in a fundamentalist approach to the Koran and the Hadith. ${ }^{36}$ Patrick Sookhdeo, a British scholar who is Director of the Institute for the Study of Islam and Christianity, has argued that Muslims need to recognize that war and terrorism feature in their teachings. He has called for Muslims to stop their self-deception that Islam is a religion of peace and "with honesty recognise the violence that has existed in their history in the same way that Christians have had to do."37 Similar calls for Muslims to engage in the ideological battle for the future of Islam have come

31 Anne Speckhard, "Understanding Suicide Terrorism: Countering Human Bombs and Their Senders," in Topics for Terrorism: Toward a Transatlantic Consensus on the Nature of the Threat, eds. Jason S. Purcell and Joshua D. Weintraub (Washington, D.C.: Atlantic Council Publications, 2005).

32 See, for example, “Just over a Year Since the Terrorist Attacks on London's Transport System on July 7, 2005, Britain is on Alert Again,” Radio Free Europe/Radio Liberty (16 August 2006).

33 Office of National Statistics, Focus on Ethnicity and Religion 2006 (October 2006); available at www.statistics.gov.uk/StatBase/Product.asp?vlnk=14629.

34 Home Office, Official Account, 26.

35 Duncan Gardham, “Muslim was Planning Dirty Bomb Attack in UK," The Daily Telegraph (13 October 2006).

36 See, for example, Sam Harris, The End of Faith: Religion, Terror and the Future of Reason (New York: W.W. Norton \& Company, 2005); Farhad Khosrokhavar, Suicide Bombers: Allah's New Martyrs (London: Pluto Press, 2005). Of particular note are the remarks of the former Archbishop of Canterbury, Lord Carey, quoted in Mark Tooley "Department of Strange Bedfellows,” The Weekly Standard (29 September 2006).

37 Patrick Sookhdeo, “The Myth of Moderate Islam,” The Spectator 298:9234 (30 July 2005): 12-15. 
from scholars and commentators on both sides of the Atlantic. ${ }^{38}$ However, British official efforts to counter the extremist ideologies that support terrorism do not address the religious debate directly. The government is naturally reluctant to intervene in a matter that is best left to Islamic clerics and scholars. At the same time, there is growing official frustration that Muslim community leaders are not doing enough to tackle the extremism that appears to be flourishing in their midst. ${ }^{39}$

\section{The Background and Motivation of “Home-Grown” Terrorists}

What of the background, influences, and motivations of the actual terrorists or wouldbe terrorists themselves? Clearly, with many investigations ongoing, and some cases still sub judice, it is impossible to obtain a complete picture of what has inspired British Muslims to kill their fellow citizens. The official report by the Home Office into the July 2005 bombings offers the most comprehensive analysis to date, but as the authors acknowledge, much research remains to be done. Nevertheless, the personal profiles offered in the report provide useful insights into the radicalization process, and are therefore summarized below. ${ }^{40}$

The bombers were aged between eighteen and thirty. Two were married with children. Three of them were second-generation British citizens of Pakistani origin who grew up in an area described by the report as "deprived," although none were considered poor by the standards of the area. The fourth bomber was born in Jamaica and had an unstable family background, although the report does not attempt to link this directly to his radicalization. Mohammed Sidique Khan, the oldest and the presumed leader, was a well-respected teaching assistant and youth worker who was considered a role model for young people. He is also described as someone who used drugs and alcohol and "got into fights" in his youth, but had become religiously devout and cleanliving from the late 1990s onwards. In view of the psychological profile identified by Speckhard noted above, it is interesting that one of the suspects arrested following the August 2006 airline bomb plot is also reported to have had trouble with drugs and alcohol before a recent life-changing conversion to Islam. ${ }^{41}$ Shazad Tanweer had recently left university, Hasib Hussein had just completed school, and Jermaine Lindsay had worked in a series of odd jobs.

38 See, for example, M. Zuhdi Jasser, "Muslims in the Crosshairs," Washington Times (3 August 2006); and Shmuel Bar, “The Religious Sources of Islamic Terrorism,” Policy Review 125 (June/July 2004); available at www.policyreview.org/jun04/bar.html.

39 See David Hencke and Hugh Mair, "Kelly: Imams Failing to Deter Extremism,” The Guardian (U.K.) (14 August 2006); and Toby Helm, "Back British Values or Lose Grants, Kelly tells Muslim Groups,” The Daily Telegraph (12 October 2006).

40 The investigators' description of the background and lifestyle of the bombers is in Home Office, Official Account, 13-18.

41 Jumana Farouky, "Profile the Suspects: Converts to Islam,” Time (11 August 2006); available at www.time.com/time/world/printout/0,8816,1225687,00.html. 
The Home Office report claims that the backgrounds of the individuals were "unexceptional," and John Reid described the bombers as "ordinary British citizens."42 However, the bombers' behavior hardly merits these descriptions. All four were particularly devout by normal Muslim standards in the U.K. ${ }^{43}$ Lindsay was a recent convert to Islam who seems to have been strongly influenced by the extremist preacher Abdallah al Faisal, who is now serving a prison sentence for incitement to murder and racial hatred. The others were reported to have become increasingly strict in their religious observance in recent years. ${ }^{44}$ Investigations have shown that the group was in contact with other extremists in the U.K., and both Khan and Tanweer are known to have visited Pakistan, where it is thought that that they met with Al Qaeda members. ${ }^{45}$ Like other European jihadists, Khan, Tanweer, and Hussein appear to have bonded through mosques, youth clubs, a gym, and an Islamic bookshop. Some acquaintances interviewed for the report claimed that some of these establishments were "centers of extremism," but the evidence is far from conclusive. The group also took part in outdoor activities such as camping and white-water rafting, which may have offered opportunities for further bonding and ideological indoctrination. ${ }^{46}$

In a video made by Khan, he claimed that perceived injustices by the West against the Muslim world justified violence to protect and avenge other Muslims. His message was couched in religious terms, and his separate last will and testament stressed the importance of martyrdom as evidence of commitment to Islam. ${ }^{47}$ Tanweer's statement, which did not emerge until the anniversary of the bombings in 2006, is much more explicit, as it refers not only to the religious duties of all Muslims to fight for Allah, but also to the British presence in Afghanistan and Iraq and support for the United States and Israel. ${ }^{48}$ Few concrete facts are known about the motivation of the other bombers, although Hussein and Lindsay were noted to have expressed extremist views at school. ${ }^{49}$

42 House of Commons Hansard Debates for 11 May 2006 (pt 0126) Col. 522.

43 For example, in the NOP Poll of April 2006, 54 percent of Muslims surveyed stated that they never attended a mosque, or only did so on special occasions.

44 Devout religious observance has been a notable feature of the behavior of suspects in other terrorist cases in the U.K., although traditional dress and displays of religion have become more popular generally with young Muslims in the last decade. See Sean Rayment, "MI5 Fears Silent Army of 1,200 Biding Its Time in the Suburbs,” The Daily Telegraph (4 June 2006).

45 Intelligence and Security Committee, 12.

46 An interest in outdoor activities appears to have been a common factor for members of other terrorist cells disrupted before and after July 2005.

47 Home Office, Official Account, 19.

48 The full text of Tanweer's statement is available from the Middle East Media Research Institute (MEMRI), Clip No. 1186 (8 July 2005); available at www.memritv.org/Transcript.asp? P1=1186. In a typical example of "black propaganda," the broadcast implicates the U.K. in "the genocide of over 150,000 innocent Muslims in Fallujah."

49 Home Office, Official Account, 19. 
The final section of the Home Office report attempts to place the radicalization process of the July 2005 bombers in a wider context, given what is known about other Islamist terrorist conspiracies in the U.K. ${ }^{50}$ First, family background and social or economic circumstances appear to give no indication of an individual's relative vulnerability to radicalization. ${ }^{51}$ Attendance at a mosque with links to extremists is often a factor, although the report acknowledges that radicals increasingly use private houses and other premises as meeting places in order to avoid detection. Not surprisingly, exposure to extremist spiritual leaders is also identified as a common contributor to radicalization, not only through direct contacts, but also often by means of audio-visual material and the Internet. Mentorship is described as having a potentially "critical” impact. Mentors, like Khan, have helped to identify and groom potential terrorist recruits, and help them to bond with like-minded individuals.

The Home Office report identifies common stages in the grooming process. Initially, mentors place an emphasis on being a devout Muslim, without introducing an extremist agenda. Potential recruits are then subjected to propaganda illustrating the abuse and persecution of Muslims around the world. Religious justifications from the Koran and Hadith are then given for violent jihad and, in the case of suicide attacks, the importance and rewards of martyrdom are emphasized. The report concludes that there is little evidence of compulsion. Instead, the mentors rely on building individual commitment to the cause, along with group identity and solidarity.

\section{U.K. Government Policies to Address Radicalization}

The British government's long-term strategy for tackling terrorism is known as "Contest." The strategy aims to both reduce the terrorist threat to the United Kingdom and its vulnerability to a terrorist attack. Counterterrorist activities are divided into four principal strands, known as "Prevent," "Pursue," "Protect," and "Prepare.,"52 CIST measures form the core of the "Prevent" strand, which focuses on reducing the number of individuals that might be inclined to support Islamist terrorism or become terrorists themselves. The government has recognized that it is no longer possible to separate the domestic and international dimensions of the threat, and the strategy reflects this. In July 2006, following detailed analysis of the context of the July 2005 bombings, the government launched an unclassified strategy paper for countering international ter-

50 Ibid., 31-32.

51 This conclusion is supported by initial reports on the backgrounds of suspects in the August 2006 transatlantic flights bombing plot. See "Who are the Terror Suspects," BBC News (11 August 2006); available at http://news.bbc.co.uk/gov/pr/fr/-/1/hi/uk/47832215.stm. See also Kamran Siddique "My Friend: The Football Fan who Dreamed of Being a Doctor," The Guardian (U.K.) (15 August 2006).

52 "Contest" is a classified document, but a general description of the strategy is given in the official reports on the July 2005 bombings referred to here. The Home Secretary also describes Contest in Hansard Debates for 10 July 2006, op. cit., Columns 1115-18. 
rorism based on "Contest." This provides the best summary of U.K. CIST policies to date. $^{53}$

Reflecting the level of threat, the U.K. has gone farther than its European partners to engage with Muslim communities and produce a comprehensive package of measures to address radicalization. By comparison, European counterterrorism strategies with respect to CIST tend to provide general statements of intent rather than policy specifics. ${ }^{54}$ U.K. thinking on CIST is essentially sober and pragmatic, rather than idealistic. Whereas the United States' Quadrennial Defense Review (QDR) of 2006 states that "the appeal of freedom is the best long-term counter to the ideology of the extremists," ${ }^{55}$ the U.K. places noticeably less emphasis in official documents on an ideological struggle between democratic freedoms and extremism.

The first set of U.K. CIST measures comes under the official heading "Tackling disadvantage and supporting reform, ${ }^{, 66}$ and reflects the government's belief that inequalities and lack of opportunity in the U.K. and abroad contribute to Muslim radicalization. The Improving Opportunities, Strengthening Society policy paper outlines a broad race and community cohesion strategy launched in January $2005 .{ }^{57}$ It is intended to help Muslims and other minorities improve their educational performance, employment opportunities, and housing conditions. This initiative includes support to help Muslim faith-based organizations engage with the government, other faiths, and civil society more effectively. The Commission on Integration and Cohesion was announced in June 2006. ${ }^{58}$ The commission works with Muslim communities to examine causes of tension, barriers to integration, and the means of improving the capacity of these communities to resist extremist ideologies. The commission is due to report its findings to the government in July 2007.

With the issue of the Foreign and Commonwealth Office's (FCO) strategic priorities in March 2006, the government reaffirmed that countering terrorism was the de-

53 Countering International Terrorism, 11-16.

${ }^{54}$ See, for example, Council of the European Union, The European Union Strategy for Combating Radicalisation and Recruitment to Terrorism, 14781/1/05 REV 1 (Brussels: European Union, 24 November 2005), 1-6; and France's strategy document, Prevailing Against Terrorism: White Paper on Domestic Security Against Terrorism (Paris: Le documentation Française, 2006), 115-22.

55 U.S. Department of Defense, Quadrennial Defense Review Report (Washington, D.C.: Government Printing Office, 6 February 2006), 22; available at www.globalsecurity.org/ military/library/policy/dod/qdr-2006-report.pdf. See also National Security Advisor Stephen Hadley's speech to the United States Institute of Peace regarding the National Security Strategy, delivered on 16 March 2006; text available at www.state.gov/r/pa/ei/wh/63257.htm.

Countering International Terrorism, 11.

57 Available from the Home Office website, at www.homeoffice.gov.uk/documents/improvingopportunity-strat?view=Binary.

58 The Terms of Reference of the Commission are available from the Department for Communities and Local Government website, at www.communities.gov.uk/ index.asp?id=1501522. 
partment's foremost task. ${ }^{59}$ The government claims that the FCO’s Global Opportunities Fund supports projects and initiatives intended to promote effective and accountable governments, democratic institutions, and human rights in the Muslim world. ${ }^{60}$ In view of the perceived role of schools in the radicalization process, the FCO has focused on educational reform, including the establishment of partnerships with madrasas in Pakistan and Bangladesh and enhanced scholarship and exchange programs targeted at Muslim countries. As a contribution to the "battle of ideas," the FCO has also increased its complement of Arabic and Urdu speakers in order to be more proactive in explaining British foreign policy and highlighting the development aid and security assistance provided by the U.K. to Muslims in places such as Kosovo, Bosnia, and Kashmir.

The second set of CIST activities falls under the heading "Deterring those who facilitate terrorism." 61 The main focus here is on enhancements to counterterrorism legislation to combat the spread of extremist ideas. The Terrorism Act 2006 made it a criminal offense to encourage acts of terrorism, including the distribution of publications advocating or glorifying terror. ${ }^{62}$ It also broadened the criteria that can be used to proscribe organizations that promote terrorism. A list of so-called "Unacceptable Behaviors" was published by the Home Office in August $2005 .^{63}$ This list identified activities that could lead to non-U.K. citizens being excluded or deported, namely the use of any medium to foster hatred or justify terrorism. The Immigration, Asylum and Nationality Act 2006 has also been introduced in support of these measures to facilitate deportation. ${ }^{64}$ This remains a contentious issue, as there are tensions between attempts to speed up the process of deportation and the country's obligations under the European Convention on Human Rights not to return individuals to states where they may be subject to torture or abuse. ${ }^{65}$

Mr. Andy Hayman, Assistant Commissioner on Special Operations, Metropolitan Police, has described prisons as a "hot spot" for radicalization. ${ }^{66}$ Consequently, initiatives to prevent radicalization within the prison population are also included under the "deterrence" category. ${ }^{67}$ Proposals include specialist training for imams working within the prison service, a mentoring program to identify prisoners susceptible to extremist

59 Foreign and Commonwealth Office, Active Diplomacy for a Changing World: The UK's International Priorities, Cm. 6762 (London: The Stationery Office, March 2006), 29; available at www.fco.gov.uk/Files/kfile/fullintpriorities2006.pdf.

60

61

62

63

64

65

66

67

Countering International Terrorism, 11.

Countering International Terrorism, 12.

Full text available at www.opsi.gov.uk/acts/acts2006/60011-b.htm.

See “Acts of Hate: Full List of Deportation Acts,” TimesOnline (24 August 2005); available at www.timesonline.co.uk/printFriendly/0,,1-20749-1748674-20749,00.html.

Full text available at www.opsi.gov.uk/acts/acts2006/20060013.htm.

See discussion in U.K. Parliament Home Affairs Committee, Counter-Terrorism and Community Relations in the Aftermath of the London Bombings, Uncorrected Transcript of Oral Evidence (13 September 2005), 5, 11.

Home Affairs Committee, Counter-Terrorism and Community Relations, 19.

See House of Commons Hansard Written Answers for 8 March 2006 (pt 30). 
views, and support for Muslim prisoners to reintegrate into society following the end of their sentences.

The third set of measures to counter the ideologies that support terrorism is referred to under the rubric of "The battle of ideas." ${ }^{\text {" }}$ Under a project called "Preventing Extremism Together," seven community-led working groups were established as part of a major government effort to engage with Muslim community leaders, women, and young people. ${ }^{69}$ The principal recommendations from this project engendered several initiatives, including a "Scholars' Roadshow," which provides an opportunity for Islamic scholars and thinkers to argue against extremism and terrorism with young British Muslims; the creation of regional forums to bring together members of local Muslim communities, the police, and public service agencies to discuss action against both radicalization and Islamophobia; and the implementation of a Mosques and Imams National Advisory Board to examine the accreditation of imams, improve the governance of mosques, and increase interfaith activity.

At the time of writing, government action had already been completed on other recommendations, including measures to improve the academic performance of Muslim students and extend equal opportunities legislation to cover discrimination on the grounds of faith. However, there has also been criticism that the government has been tardy in addressing some proposals, ${ }^{70}$ and the Liberal Democrat peer, Lady Falkner, has dismissed the whole exercise as "a very hurried, let's-do-something sort of response rather than anything substantive." ${ }^{, 1}$ Other commentators have argued that the government may be confronting extremism in the wrong places, as available information suggests that the radicalization of individuals is taking place away from established mosques and community facilities. ${ }^{72}$

\section{CIST: The Barriers to Effective Implementation}

At a presentation in 2003, the Director General of the U.K. Security Service, Eliza Manningham-Buller, acknowledged the severity of the ideological challenge confronting British policy makers and security officials: "Breaking the link between terrorism and religious ideology will be difficult in the short term. Political dialogue and a proc-

68 Countering International Terrorism, 13.

69 Under a government reorganization of May 2006, responsibility for this project has been taken over by the Department for Communities and Local Government. For details see www.communities.gov.uk/index.asp?id=1501973.

70 See, for example, Hansard 10 July 06, op. cit., columns 1122-23.

71 Quoted in Martin Bright, When Progressives Treat with Reactionaries: The British State's Flirtation with Radical Islamism (London: Policy Exchange Limited, 2006), 26; available at www.policyexchange.org.uk.

72 See, for example, Faisal Devji, “A Muslim Militancy Born of Modernity not Mosques,” Financial Times (28 August 2006), 11. 
ess of reconciliation are not on the horizon as groups like Al Qaeda have aims that are absolute and non-negotiable."73

Since 2003, the British government has increasingly placed efforts to combat radicalization at center stage of its overall counterterrorism strategy. However, the development of a coherent program to counter extremist ideology remains a work in progress. It will take time to both fully understand the process of radicalization in the U.K. and for domestic and international policy initiatives to have an impact. The British government's efforts to sway Muslim opinion at home and abroad will continue to be hamstrung because of the unpopularity of Britain's policies in the Muslim world. It is also questionable whether efforts by the U.K. and other Western states to work through friendly Muslim governments and elites will find a receptive audience in communities where ordinary citizens are already alienated from these same governments and elites. The terrorism analyst Sebestyén Gorka claims that the West has already lost the battle for perceptions because of the immaturity of political environments in the Middle East and Central Asia and the widespread influence of anti-Western conspiracy theories in these regions. $^{74}$

CIST may be a lengthy process, but unfortunately intelligence agencies have learned that the radicalization of young Muslims can take place very rapidly. ${ }^{75}$ Inevitably, such heightened threat perception has led to a more proactive and intrusive police presence in Muslim communities. Security alerts, especially when they involve the arrest or shooting of innocent people, infuriate ordinary Muslim citizens and undermine the government's efforts to promote cooperation against radicalization. A report by the U.S. Congressional Research Service claimed that nearly 900 people had been arrested in the U.K. since 9/11 under anti-terrorism laws, but only 138 had been charged with terrorist related offenses, and only 23 actually convicted. ${ }^{76}$ The U.K.'s most senior Muslim police officer, Tarique Ghaffur, has claimed that robust police action and tougher anti-terrorism laws have discriminated against Muslims and caused distrust, anger, and alienation. ${ }^{77}$ However, government ministers and security forces face what BBC political journalist Andrew Marr has called an "appalling dilemma,", caught between overreacting to threats on the basis of unquantifiable intelligence or

73 Speech to the Royal United Services Institute, 17 June 2003; available at www.mi5.gov.uk/ output/Page210.html.

Sebestyén L.v. Gorka, “Al Qaeda and Von Clausewitz Rediscovering the Art of War," unpublished paper delivered at the U.S. Joint Special Forces University Symposium, “Countering Global Insurgency,” 2-5 May 2006.

75 Intelligence and Security Committee, 29.

76 Kristin Archick, Carl Ek, Paul Gallis, Francis T. Miko, and Steven Woehrel, European Approaches to Homeland Security and Counterterrorism, CRS Report RL33573 (Washington, D.C.: Congressional Research Service, 24 July 2006), 43; available at www.fas.org/sgp/ crs/homesec/RL33573.pdf.

77 Assistant Commissioner Tarique Ghaffur, quoted in John Steele, “Tougher Police Tactics on Terror Driving Muslims Apart, says Police Chief,” The Daily Telegraph (8 August 2006). 
not doing enough to prevent an attack and being universally condemned for inaction afterwards. After the shooting of an innocent man during a house search for a chemical device in June 2006, police in London have agreed to consult a panel of Muslim leaders before mounting counterterrorist raids or making arrests. The panel will have the opportunity to offer their assessment of the accuracy of the police intelligence and the impact of the raid on community relations. It is not yet known whether the panel will be allowed access to classified information from the Security Service. ${ }^{79}$ What is clear is that tension between the "Prevent" and "Pursue" strands of the government's counterterrorism strategy seems likely to continue.

The government's attempts to co-opt Muslim leaders in the struggle against terrorism have proved controversial, with complaints that too much weight has been given to the views of more radical elements in Muslim communities, which has left mainstream Muslims underrepresented in the consultation process. ${ }^{80}$ The situation is not helped by the need for Muslim leaders to condemn extremism but at the same time avoid being perceived by their constituents as government stooges. One of the problems confronting the government and local authorities' attempts to find credible partners to confront radicalization is that Britain's Muslims are deeply divided, and are represented by a variety of associations that are often in dispute with each other. ${ }^{81}$ The Muslim Council of Britain (MCB) is still viewed as the main voice of British Muslims, but it is challenged on the one hand by the Muslim Association of Britain (MAB), which is ideologically close to the Muslim Brotherhood, and on the other by the more liberal, Sufiinfluenced British Muslim Forum (BMF). In addition, there are a number of smaller groups, including the al Khoei Foundation, which represents the U.K.'s small population of Shiite Muslims; the British Muslim Initiative; and radical affiliates of the banned al Muhajiroun group.

Islamist organizations that claim to eschew violence, but have nevertheless been linked to extremism, create particular difficulties in a liberal democracy with a tradition of freedoms of speech and association. Recently, both the missionary group Tablighi Jamaat and the radical international political Islamist group Hizb ut-Tahrir have come under the spotlight, with calls for their proscription. ${ }^{82}$ The BMF claims to represent 80 percent of British Muslims but complains that, unlike the MCB, it lacks the ear of the government. ${ }^{83}$ In a monograph released by the conservative Policy Exchange research institute, Martin Bright, the editor of the left-wing New Statesman

79 Abdul Taher, "Police to Brief Muslims Before Terror Raids,” The Sunday Times (24 September 2006).

80 See, for example, House of Commons Hansard Debates for 5 December 2005 (pt 3), Column 593.

81 “Who Speaks for British Muslims?” The Economist (17 June 2006), 36-38.

82 See, for example, Sean O’Neill and Roger Boyes, “Islamic Missionary Group Links Alleged Plotters,” TimesOnline (17 August 2006); available at www.timesonline.co.uk/printFriendly/ 0,,1-2-2316667-2,00.html. See also "Hizb ut-Tahrir,” BBC News (6 August 2005); available at http://news.bbc.co.uk/1/hi/uk/4127688.stm.

83 “Immoderate Voices,” The Wall Street Journal (18-20 August 2006), 12. 
magazine, has accused the government of working with unrepresentative radical Islamists in both the U.K. and the Middle East. ${ }^{84}$ Bright argues that the government has treated radical Islamists in the MCB and Muslim Brotherhood as the voices of mainstream Muslim opinion, and has consequently granted them an undeserved legitimacy. He claims that "Whitehall has embraced a narrow, austere version of the (Muslim) religion" that is not helping tackle the ideology that breeds terrorism. ${ }^{85}$ The British authorities are caught in a central dilemma of the war on terror, namely the degree to which a government can establish a dialogue with political Islamists without being seen to legitimize terrorism.

The U.K.'s perception of the threat from Islamist terrorism remains grave. Peter Clarke, Scotland Yard's Head of Counterterrorism, recently told a BBC 2 interviewer that the police were monitoring thousands of people in the U.K., and described the intelligence picture as "very disturbing." ${ }^{86}$ In these circumstances, there is a real danger of polarization between Muslim communities and mainstream British society. Ghaffur has warned of a sense of separateness in Muslim communities, and the demonization of Muslims and Islam by the media. ${ }^{87}$ A You Gov poll for The Daily Telegraph in August 2006 found that 53 percent of people surveyed felt that Islam itself (as distinct from Islamic fundamentalism) posed a "major" or "some" threat to the nation. ${ }^{88}$ Only 16 percent answered positively to the statement: "Practically all British Muslims are peaceful, law abiding citizens who deplore terrorist acts as much as anyone else.” Another You Gov poll, for The Spectator in September 2006, found that 73 percent of respondents agreed that the West was engaged in a global war against Islamic terrorism.

Clearly, these polls may have been influenced by the major terrorist plot uncovered in August 2006, and the publicity surrounding the fifth anniversary of the 9/11 attacks, but nevertheless there has been a growing consensus recently from all shades of political opinion that it is time to reassert so-called mainstream British values. Part of this trend is a reaction to the perceived takeover of "political correctness," but there are also more disturbing indications that this is the beginning of a backlash against what are widely viewed as unwarranted concessions to Muslim sensitivities in the name of multiculturalism and appeasement. ${ }^{89}$ Such developments are unlikely to make the government's attempts to engage Muslim communities any easier or more successful.

84 Martin Bright, When Progressives Treat with Reactionaries. Particular criticism is directed at the "Arabists" in the FCO who advocated direct talks with Hamas and Hezbollah.

85

86

87

88

89 Bright, When Progressives Treat with Reactionaries, 12.

Peter Clarke, quoted in "Terror Police Monitor Thousands,” BBC News (2 September 2006); available at http://news.bbc.co.uk/go/pr/fr/-/1/hk/uk/5306580.stm.

Steele, “Tougher Police Tactics on Terror.” One senior government adviser in conversation with the author claimed that there was even a danger of "intifada” in British cities.

Both You Gov surveys quoted here are available at www.yougov.com.

See, for example, Patience Wheatcroft, “Multiculturalism Hasn't Worked: Let's Rediscover Britishness," The Daily Telegraph (8 October 2006); Henry Porter, "Jack Straw Should be Praised for Lifting the Veil on Taboo," The Observer (8 October 2006); and "Multi-faith Agenda Separates UK,” BBC News (10 August 2006); available at http://newsvote.bbc.uk/ mpapps/pagetools/print/news.bbc.co.uk/hi/uk_news/4801605.stm. 


\section{Conclusions}

It is still too early to judge the effectiveness of British attempts to combat Islamist radicalization. There remains only a partial understanding of both the ideological dimension of the threat and the motivation of terrorists who have mounted or attempted to mount attacks in the U.K. Nevertheless, some advances have been made. For example, it is far harder now for extremist Islamist clerics to openly preach an ideology of hatred than in the recent past. However, it remains to be seen whether the government's strenuous efforts to engage Muslims in the effort to counter the ideologies that support terrorism will prove fruitful, or fail in the face of sectarian divisions and a growing siege mentality generally within Muslim communities. The perception that British foreign policy amounts to a war against Muslims is likely to persist, as the anticipated change of Prime Minister next year is unlikely to prompt a shift in the U.K.'s international security priorities. As emphasized above, CIST measures will take time. Unfortunately, there is no guarantee that the jihadists will grant the government the time it needs to advance its CIST agenda. Another serious Islamist terrorist attack against civilians in the U.K. will likely lead to even tougher law enforcement measures that will further isolate ordinary Muslims, and—even worse-could provoke a violent backlash from elements of the white majority. Measured by any yardstick, the situation does indeed remain, in Peter Clarke's words "very disturbing." 


\section{THE QUARTERLY JOURNAL}

\section{Bibliography}

Archick, Kristin, Paul Gallis, Francis T. Miko, Steven Woehrel, and Carl Ek. European Approaches to Homeland Security and Counterterrorism. Washington, D.C.: Congressional Research Service, 2006.

Brown, Nathan J., Amr Hamzawy, and Marina Ottaway. Islamist Movements and the Democratic Process in the Arab World In Carnegie Papers No. 67. Washington, D.C.: Carnegie Endowment, 2006.

Devji, Faisal. "A Muslim Militancy Born of Modernity not Mosques." Financial Times(2006).

Frean, Alexandra, and Rajeev Syal. "Muslim Britain Split Over Martyrs of 7/7." Times Online (2006).

Gardham, Duncan. Muslim was Planning Dirty Bomb Attack in UK., 2006.

Gray, John. Al Qaeda and What It Means to be Modern. London: Faber \& Faber, 2003.

Harris, Sam. The End of Faith: Religion, Terror and the Future of Reason . New York: W. W. Norton \& Company, 2005.

Helm, Toby. "Back British Values or Lose Grants, Kelly tells Muslim Groups." The Daily Telegraph (2006).

Hencke, David, and Hugh Mair. "Kelly: Imams Failing to Deter Extremism." The Guardian (U.K.) (2006).

Karmon, Ely. "Al-Qa'ida and the War on Terror After the War in Iraq." Middle East Review of International Affairs 10, no. 1 (2006).

Makarenko, Tamara. "Takfiri Presence Grows in Europe." Jane's Intelligence Review(2005).

Nazir-Al, Michael. "Multiculturalism is to Blame for Perverting Young Muslims." The Daily Telegraph (2006).

Nesser, Petter. "Post-millennium Patterns of Jihadist Terrorism in Western EuropePart 1." Jane's Terrorism and Security Monitor (2005).

Neumann, Peter R.. "Europe's Jihadist Dilemma." Survival 48, no. 2 (2006).

Porter, Henry. "Jack Straw Should be Praised for Lifting the Veil on Taboo." The Observer (2006).

Rayment, Sean. "MI5 Fears Silent Army of 1,200 Biding Its Time in the Suburbs." The Daily Telegraph (2006). 
Reilly, Robert. The Roots of Islamist Ideology. London: Centre for Research into PostCommunist Economies, 2006.

Sageman, Marc. Understanding Terrorist Networks. Philadelphia: University of Pennsylvania Press, 2004.

Sookhdeo, Patrick. "The Myth of Moderate Islam." The Spectator (2005).

Taher, Abdul. "Police to Brief Muslims Before Terror Raids." The Sunday Times (2006).

Wiktorowicz, Quintan. "Anatomy of the Salafi Movement." Studies in Conflict and Terrorism 29, no. 3 (2006): 207-39. 